(c) American Dairy Science Association, 2006.

\title{
Major Advances in Determining Appropriate Selection Goals
}

\author{
G. E. Shook \\ Dairy Science Department, University of Wisconsin-Madison 53706-1284
}

\begin{abstract}
Substantial increases of 3,500 kg of milk, $130 \mathrm{~kg}$ of fat, and $100 \mathrm{~kg}$ of protein per cow per lactation have resulted from improvements in genetics, nutrition, and management during the past $20 \mathrm{yr}$. At the same time, the interval from calving to conception increased (unfavorable) by $24 \mathrm{~d}$. Genetics has accounted for about $55 \%$ of gains in the yield traits and about onethird of the change in interval to conception. Genetic gains in the yield traits and productive life have accumulated to around 1.7 and 1.2 genetic standard deviations since 1980. Unfavorable genetic changes in conception interval since 1980 and somatic cell score since 1990 have accumulated to 1.0 and 0.12 genetic standard deviations. The most important advance in selection indexes has been the introduction of nonyield traits. Advances in selection indexes have gone hand in hand with advances in data collection and genetic evaluation. As new traits were recorded in dairy management databases and as genetic evaluations were developed for these traits, they were incorporated into selection indexes. Until 1994, when somatic cell score and productive life were introduced, selection indexes provided by USDA included only yield traits. In 2000, composite type indexes for udder, feet and legs, and body size were added. Daughter pregnancy rate and service sire- and daughter-calving ease were included in 2003. The lifetime merit indexes introduced in 2003 have, for the first time, resulted in theoretical selection responses in the desired direction for all traits. During this time, the percentage relative economic weights in selection indexes increased from 0 to $45 \%$ for the nonyield traits. Selection emphasis on nonyield traits should continue to increase as additional traits (e.g., calf survival, metabolic disease, and male fertility) are introduced in the future. Wide variation exists among countries in traits included in selection indexes and in relative economic weights. Molecular genetic studies have identified many chromosome regions with potentially important major genes for economic traits. Use
\end{abstract}

Received May 27, 2005.

Accepted July 22, 2005

E-mail: geshook@wisc.edu of DNA markers for genetic improvement is currently limited by lack of precision in marker location. Discovery of major genes will be accelerated by the availability of the bovine genome sequence, comparative genome maps and genome sequences across species, and increased use of breed crosses in molecular studies. As major genes are identified, their effects will be incorporated into genetic evaluations and selection indexes.

Key words: selection index, total economic merit

\section{INTRODUCTION}

"Turn your attention towards reducing the cost of production so that there is a margin of profit even at low prices." This admonition from W. D. Hoard, founder of Hoard's Dairyman magazine in 1885, characterizes the most important change in selection index formulation during the past quarter-century. Since 1994, selection indexes in the United States have evolved from being entirely based on milk revenues to now including 8 traits that represent production costs.

In the United States, selection indexes are developed by the breed associations and by the USDA Animal Improvement Programs Laboratory (AIPL). The AIPL indexes and comparisons with indexes published in other countries are the focus of this article. Although AIPL staff coordinates formulation of selection indexes, broad input is sought from the AI industry, breed associations, DHIA organizations, researchers, extension specialists, and producers. Advances in selection indexes have gone hand in hand with advances in data collection and genetic evaluation. As new traits were recorded in dairy management databases and as genetic evaluations (predicted transmitting ability, PTA) were developed for these traits, they were incorporated into selection indexes. Advances in genetic evaluations are outlined in a companion article. The American Dairy Science Association observed the 50th anniversary of publication of the founding article on selection index by L. N. Hazel with a symposium in 1993.

\section{BACKGROUND}

A selection index in its simplest form is a prediction of animals' breeding merits for total economic merit 
Table 1. Holstein breed averages by year of birth ${ }^{1}$

\begin{tabular}{lrrrrr}
\hline & \multicolumn{5}{c}{ Year of birth } \\
\cline { 2 - 6 } Trait $^{2}$ & 1980 & 1985 & 1990 & 1995 & 2000 \\
\hline Milk $^{3}{ }^{3} \mathrm{~kg}$ & 8,003 & 8,616 & 9,458 & 10,605 & 11,505 \\
Fat, $^{3} \mathrm{~kg}$ & 290 & 312 & 346 & 384 & 419 \\
Protein, $^{3} \mathrm{~kg}$ & 241 & 253 & 280 & 314 & 345 \\
PL, mo & 25.8 & 24.8 & 24.1 & 23.8 & 24.7 \\
DPR, \% & 27.5 & 26.3 & 25.2 & 22.3 & 21.2 \\
SCS & $\mathrm{NA}^{4}$ & $\mathrm{NA}$ & 3.2 & 3.1 & 3.1 \\
\hline
\end{tabular}

${ }^{1}$ Animal Improvement Programs Laboratory. Genetic and phenotypic trends, November 2004. http://aipl.arsusda.gov/dynamic/trend/ current/trndx.html. Accessed Jan. 4, 2005.

${ }^{2} \mathrm{PL}=$ Productive life DPR $=$ daughter pregnancy rate.

${ }^{3}$ Adjusted to twice-daily milking and $305 \mathrm{~d}$ in milk at mature age. ${ }^{4} \mathrm{NA}=$ Not available.

(TEM). Total economic merit is a combination of an animal's (denoted by i) predicted transmitting abilities $\left(\mathrm{PTA}_{\mathrm{ij}}\right)$ for all economically important traits, with each trait $(j)$ weighted by its net economic value $\left(a_{j}\right)$ :

$$
\mathrm{TEM}_{\mathrm{i}}=\mathrm{a}_{1} \times \mathrm{PTA}_{\mathrm{i} 1}+\mathrm{a}_{2} \times \mathrm{PTA}_{\mathrm{i} 2}+\ldots+\mathrm{a}_{\mathrm{n}} \times \mathrm{PTA}_{\mathrm{in}} .
$$

The economic value for a trait represents the contribution to change in profit per unit change of a trait, given no change in any other trait. It is not necessary to use the actual economic values in TEM, but the relative economic values, e.g., $\left(a_{j}\right) /\left(a_{1}\right)$, should be correct. Predicted transmitting ability measures the average value of genes transmitted from the individual to progeny and is derived from performance of the animal and known relatives.

Effective selection indexes depend on proper formulation of TEM in terms of the measure of TEM, appropriate relative economic weights, and inclusion of the most important traits. The TEM may be measured in terms of profit per month of herd life, lifetime profit, economic efficiency (revenues/costs), or production efficiency (costs/revenues). Selection indexes have their utility in combining the PTA values for several traits into a single summary value for each animal. Ranking animals on TEM values should be the first step in selecting breeding animals from among candidates. This ensures that the animals ultimately selected are among the highest in TEM.

Relative economic weights determine how selection pressure and selection response are distributed among traits. Increasing percentage weights on some traits requires decreasing weights on others with consequent changes in trait responses. A properly formulated index directs selection intensity toward traits in a way that optimally exploits the economic values, heritabilities, and genetic variances of traits as well as the genetic and phenotypic correlations among traits.
Table 2. Gain in Holstein average breeding value for selected years of birth relative to cows born in $1980^{1}$

\begin{tabular}{lccccc}
\hline & \multicolumn{5}{c}{ Year of birth } \\
\cline { 2 - 5 } Trait $^{2}$ & 1985 & 1990 & 1995 & 2000 & SDBV $^{3}$ \\
\hline Milk, $^{4} \mathrm{~kg}$ & 466 & 980 & 1545 & 2083 & 1220 \\
Fat, ${ }^{4} \mathrm{~kg}$ & 17 & 38 & 54 & 70 & 42 \\
Protein, ${ }^{4} \mathrm{~kg}$ & 10 & 25 & 41 & 59 & 32 \\
PL, mo & 1.2 & 1.8 & 2.6 & 3.1 & 2.5 \\
DPR, \% & -0.8 & -1.6 & -2.1 & -2.1 & 2.1 \\
SCS & NA $^{5}$ & 0 & 0.02 & 0.04 & 0.34 \\
\hline
\end{tabular}

${ }^{1}$ Animal Improvement Programs Laboratory. Genetic and phenotypic trends November 2004. http://aipl.arsusda.gov/dynamic/trend/ current/trndx.html. Accessed Jan. 4, 2005.

${ }^{2} \mathrm{PL}=$ Productive life $; \mathrm{DPR}=$ daughter pregnancy rate.

${ }^{3} \mathrm{SDBV}=$ Standard deviation of breeding value. Genetic gain divided by SDBV measures accumulated selection intensity.

${ }^{4}$ Adjusted to twice-daily milking and $305 \mathrm{~d}$ in milk at mature age.

${ }^{5} \mathrm{NA}=$ Not available.

When the correct relative economic weights are used, the rate of genetic improvement in TEM is maximized.

\section{GENETIC AND PHENOTYPIC TRENDS}

Remarkable increases in yield traits have occurred since 1980. Holstein breed averages are given in Table 1 for cows on DHI, included in the national genetic evaluation program, and born in selected years. These increases reflect improvements in genetics, nutrition, management, and animal health. Among the nonyield traits, a small improvement in SCS and a decline of 1 mo in productive life occurred.

The decline in reproductive performance in US Holsteins has been well documented. Table 1 shows a 6\% decline in pregnancy rate since 1980 . This is equivalent to an increase of $24 \mathrm{~d}$ open (interval from calving to conception). A study of herds with continuous reporting from 1976 to 1999 in 10 southeastern states is characteristic of national trends. Average days open increased by more than $40 \mathrm{~d}$ between 1982 and 1999 in Holsteins and by more than $30 \mathrm{~d}$ between 1988 and 1999 in Jerseys. These trends increased by an increasing amount from year to year. Conception rates in both breeds decreased from about 50\% in the early 1980s to about 34\% in 1999.

Genetic improvement in dairy cattle is driven primarily by the array of bulls provided by the AI industry and secondarily by the choices producers make among the bulls available. Selection indexes influence selection decisions at both levels. Other factors that play into these decisions are advertising and popularity, semen cost, and individual type and production traits. Genetic gains since 1980 are shown in Table 2. Genetics has accounted for more than 55\% of phenotypic gains in the yield traits and about one-third of the 
Table 3. Relative economic weights (\%) for selected US selection indexes ${ }^{1}$

\begin{tabular}{|c|c|c|c|c|c|c|c|c|}
\hline \multirow[b]{2}{*}{ Trait $^{3}$} & \multicolumn{8}{|c|}{ Index ${ }^{2}$ (year of introduction) } \\
\hline & $\begin{array}{l}\text { MF\$ } \\
(1971)^{4}\end{array}$ & $\begin{array}{l}\text { MFP\$ } \\
(1976)^{5}\end{array}$ & $\begin{array}{l}\text { CY\$ } \\
(1984)^{6}\end{array}$ & $\begin{array}{l}\mathrm{NM} \$ \\
(1994)^{5}\end{array}$ & $\begin{array}{l}\text { LNM } \\
(2000)^{5}\end{array}$ & $\begin{array}{l}\text { LFM } \\
(2003)^{4}\end{array}$ & $\begin{array}{l}\text { LNM } \\
(2003)^{5}\end{array}$ & $\begin{array}{l}\text { LCM } \\
(2003)^{6}\end{array}$ \\
\hline Milk & 52 & 27 & -2 & 6 & 5 & 24 & 0 & -10 \\
\hline Fat & 48 & 46 & 45 & 25 & 21 & 22 & 22 & 18 \\
\hline Protein & & 27 & 53 & 43 & 36 & 9 & 33 & 36 \\
\hline PL & & & & 20 & 14 & 11 & 11 & 9 \\
\hline SCS & & & & -6 & -9 & -9 & -9 & -7 \\
\hline DPR & & & & & & 7 & 7 & 5 \\
\hline SSCE & & & & & & -2 & -2 & -2 \\
\hline DCE & & & & & & -2 & -2 & -2 \\
\hline Udder & & & & & 7 & 7 & 7 & 6 \\
\hline Feet and legs & & & & & 4 & 4 & 4 & 3 \\
\hline Size & & & & & -4 & -3 & -3 & -2 \\
\hline \multicolumn{9}{|c|}{${ }^{1}$ From VanRaden, 2004.} \\
\hline \multicolumn{9}{|c|}{$\begin{array}{l}{ }^{2} \text { Indexes: MF } \$ \text { = milk-fat dollars; MFP } \$=\text { milk-fat-protein dollars; CY } \$=\text { cheese yield dollars; NM } \$= \\
\text { net merit dollars; LFM = lifetime fluid merit; LNM = lifetime net merit; LCM = lifetime cheese merit. } \\
{ }^{3} \text { Traits: PL = productive life; DPR = daughter pregnancy rate; SSCE = service sire calving ease; DCE = } \\
\text { daughter calving ease. }\end{array}$} \\
\hline
\end{tabular}

decline in pregnancy rate. Genetic and phenotypic trends were in opposite directions for productive life and SCS. Genetic merit for productive life has increased by 3 mo whereas breed average has declined by 1 mo. Breeding value for SCS has increased (unfavorable) by 0.04 points whereas breed average has improved (decreased) by 0.1 points. Standard deviation of breeding value measures the opportunity for genetic change. Relative strength or intensity of selection can be measured by dividing gains in breeding value by the standard deviation of breeding value (Table 2). Gains in the yield traits and productive life have accumulated to around 1.7 and 1.2 standard deviations, respectively. Genetic declines in pregnancy rate since 1980 and SCS since 1990 have accumulated to 1.0 and 0.12 standard deviations. Selection pressures have been moderately strong on productive life (favorable) and pregnancy rate (unfavorable), but weak on SCS.

\section{EVOLUTION OF SELECTION INDEXES}

\section{The United States}

Percentage relative economic weights for selection indexes used in the United States since 1971 are in Table 3. Lower values are desirable for SCS, calving ease, and size, so negative weights are applied for these traits. The indexes shown represent the first implementation of major changes in the indexes. Smaller incremental changes were made during intervening years. Until 1994, when SCS and productive life were introduced, indexes included only yield traits. In 2000, composite type indexes for udder, feet and legs, and body size were added. Daughter pregnancy rate and service sire- and daughter-calving ease were included in 2003. Except for the type traits, new traits were included in the selection indexes near the time that genetic evaluations became available. As new traits were added to the indexes, relative weights for previous traits were necessarily reduced.

Another dimension in the evolution of the indexes was the economic measure represented by the indexes. From 1971 to 1994, indexes measured differences among progeny in total milk revenues for one daughter for one mature lactation. Upon introduction of nonyield traits in 1994, it became necessary to change the economic measure to milk income over feed cost, but the measure continued to represent a single, mature lactation. In 2000 , the index measure was changed to lifetime rather than single lactation net income. The lifetime merit indexes represent daughter revenues minus costs for 3 lactations, more or less, depending on the individual's genetic evaluation for productive life. And in place of yield at mature age, yield values were adjusted downward to average age of production.

Relative weights for 3 indexes are shown for 2003: Lifetime Fluid Merit is appropriate for markets that do not pay for protein, Lifetime Net Merit for markets that pay an average price for protein, and Lifetime Cheese Merit for milk priced on a cheese-yield basis. Fluid Merit is designed for regions of the country, primarily the southeast, where milk markets do not pay 
SHOOK

Table 4. Correlations of trait PTA with selection index values for selected US indexes ${ }^{1}$

\begin{tabular}{llllllllr}
\hline & \multicolumn{7}{c}{ Index (year of introduction) } \\
\cline { 2 - 8 } Trait $^{2}$ & $\begin{array}{l}\text { MF\$ } \\
(1971)^{3}\end{array}$ & $\begin{array}{l}\text { MFP\$ } \\
(1976)^{4}\end{array}$ & $\begin{array}{l}\text { CY\$ } \\
(1984)^{5}\end{array}$ & $\begin{array}{l}\text { NM\$ } \\
(1994)^{4}\end{array}$ & $\begin{array}{l}\text { LNM } \\
(2000)^{4}\end{array}$ & \multicolumn{1}{l}{$\begin{array}{l}\text { LFM } \\
(2003)^{3}\end{array}$} & \multicolumn{1}{l}{$\begin{array}{l}\text { LNM } \\
(2003)^{4}\end{array}$} & \multicolumn{1}{c}{$\begin{array}{l}\text { LCM } \\
(2003)^{5}\end{array}$} \\
\hline Milk & 0.86 & 0.81 & 0.70 & 0.75 & 0.73 & 0.77 & 0.65 & 0.58 \\
Fat & 0.83 & 0.86 & 0.87 & 0.75 & 0.73 & 0.70 & 0.73 & 0.73 \\
Protein & 0.82 & 0.88 & 0.90 & 0.90 & 0.87 & 0.77 & 0.82 & 0.83 \\
PL & 0.10 & 0.10 & 0.10 & 0.41 & 0.45 & 0.52 & 0.50 & 0.48 \\
SCS & -0.04 & -0.03 & -0.02 & -0.21 & -0.28 & -0.34 & -0.31 & -0.29 \\
DPR & -0.24 & -0.22 & -0.20 & -0.03 & -0.04 & 0.08 & 0.10 & 0.09 \\
SSCE & -0.08 & -0.09 & -0.09 & -0.14 & -0.13 & -0.21 & -0.21 & -0.21 \\
DCE & -0.03 & -0.03 & -0.02 & -0.09 & -0.10 & -0.19 & -0.17 & -0.17 \\
Udder & -0.13 & -0.14 & -0.14 & -0.03 & 0.09 & 0.12 & 0.10 & 0.10 \\
Feet and legs & -0.01 & -0.01 & -0.01 & 0.04 & 0.12 & 0.13 & 0.12 & 0.11 \\
Size & -0.04 & -0.05 & -0.06 & -0.11 & -0.11 & -0.10 & -0.11 & -0.11 \\
\hline
\end{tabular}

\footnotetext{
${ }^{1}$ Indexes: MF $\$$ = Milk-fat dollars; MFP $\$=$ Milk-fat-protein dollars; CY $\$=$ Cheese yield dollars; NM $\$=$ Net merit dollars; LFM = Lifetime fluid merit; LNM = Lifetime net merit; LCM = Lifetime cheese merit.

${ }^{2}$ Traits: $\mathrm{PL}=$ productive life $\mathrm{DPR}=$ daughter pregnancy rate; $\mathrm{SSCE}=$ service sire calving ease DCE = daughter calving ease.

${ }^{3}$ Revenues based on milk and fat yield.

${ }^{4}$ Revenues based on milk, fat, and protein yield.

${ }^{5}$ Revenues based on cheese yield.
}

for protein. Net Merit is the most widely used of the lifetime indexes. These indexes trace their origins, respectively, to Milk-Fat \$ (1971), Milk-Fat-Protein \$ (1976), and Cheese Yield \$ (1984). The 3 lifetime merit indexes place the same economic values on the nonyield traits, fat yield, and milk with $3.0 \%$ true protein and $3.5 \%$ fat. They differ only in the economic values assigned to milk volume and protein yield in a way that higher protein values result in correspondingly lower values for milk volume.

Correlations of trait PTA with selection index values are shown in Table 4 for the indexes in Table 3. Genetic changes occur in nonindex traits through their genetic correlations with index traits. When selection is based strictly on an index, genetic responses of traits are proportional to the correlations in Table 4. Because selections are based on factors in addition to an index, actual selection responses differ from these predicted responses. Specifically, the correlations in Table 4 represent each trait's selection response as a fraction of selection response that would be obtained from single trait selection for the trait. Negative responses for SCS, calving ease, and size are favorable, whereas positive responses are desired for other traits.

Expected selection outcomes from the indexes have clearly changed over time. The lifetime merit indexes introduced in 2003 have, for the first time, resulted in theoretical selection responses in the desired direction for all traits. The addition of productive life and SCS in 1994 has resulted in substantially more favorable expected selection responses for those traits. Introduction of productive life in 1994 and body size composite in 2000 have doubled the downward selection pressure on size. Adding udder composite and feet and legs composite to the indexes in 2000 have reversed the previous downward trend in those traits. Incorporation of calving ease in 2003 has nearly doubled the rate of improvement in calving ease. And introduction of daughter pregnancy rate in 2003 has reversed the previously downward genetic trend in reproductive performance; however, the rate of improvement is slight. Relative responses in the yield traits have been influenced by addition of the nonyield traits and a shift in index weights away from milk volume toward protein. The result is slightly slower increases in protein yield, moderately slower increases in fat yield, and somewhat more influence on milk yield. In spite of the reduced gains in yield traits, the rate of gain in TEM has increased with the addition of nonyield traits assuming that the recent relative economic weights are correct.

\section{Other Countries}

Relative economic weights for recent selection indexes in 4 other countries are provided in Table 5 . These countries were chosen for their large differences from recent US indexes. The differences among countries are due to differences in milk markets, production systems, feed supply and cost, availability of data, and industry goals. Milk production in these countries, unlike the United States, is constrained by production quotas or land base or both. All of these indexes place high value on protein yield. Three of them assign 
Table 5. Relative economic weights (\%) for recent selection indexes in selected countries

\begin{tabular}{|c|c|c|c|c|c|}
\hline \multirow[b]{2}{*}{ Trait $^{1}$} & \multicolumn{4}{|c|}{ Country } & \multirow[b]{2}{*}{$\begin{array}{l}\text { LNM } \\
2003^{2}\end{array}$} \\
\hline & Canada & $\begin{array}{l}\text { New } \\
\text { Zealand }\end{array}$ & $\begin{array}{l}\text { The } \\
\text { Netherlands }\end{array}$ & $\begin{array}{l}\text { United } \\
\text { Kingdom }\end{array}$ & \\
\hline Milk & 0 & -17 & -14 & -18 & 0 \\
\hline Fat & 14 & 6 & 8 & 18 & 22 \\
\hline Protein & 43 & 41 & 35 & 41 & 33 \\
\hline PL & 8 & 5 & 12 & 17 & 11 \\
\hline SCS & -3 & -6 & -11 & -4 & -9 \\
\hline DPR & & 10 & 7 & & 7 \\
\hline SSCE & & & -5 & & -2 \\
\hline DCE & & & -5 & & -2 \\
\hline Udder & 17 & & & & 7 \\
\hline Feet and legs & 11 & & 3 & 3 & 4 \\
\hline Size & 4 & -15 & & & -3 \\
\hline
\end{tabular}

${ }^{1}$ Traits: $\mathrm{PL}=$ productive life; $\mathrm{DPR}=$ daughter pregnancy rate; $\mathrm{SSCE}=$ service sire calving ease $; \mathrm{DCE}=$ daughter calving ease.

${ }^{2}$ The US Lifetime Net Merit index.

strong negative weights to milk volume. The net effect is selection toward higher protein percentages. The Canadian index places high weights on type composites for udder and feet and legs; the New Zealand index assigns a strong negative weight to body size to increase feed efficiency; and the United Kingdom gives high emphasis to productive life.

Correlations between index values and trait PTA are in Table 6 . These correlations are based on US genetic variances and genetic correlations. Therefore, they represent responses expected if the indexes were applied in the US Holstein population; they are not the responses expected in the indicated countries.

\section{SELECTION INDEX TRAITS}

\section{Yield Traits}

The first selection index published in 1971 by AIPL included only milk and fat yield. Protein testing began

Table 6. Correlations of trait PTA with selection index values for selected countries

\begin{tabular}{|c|c|c|c|c|c|}
\hline \multirow[b]{2}{*}{ Trait $^{1}$} & \multicolumn{4}{|c|}{ Country } & \multirow[b]{2}{*}{$\begin{array}{l}\mathrm{LNM} \\
2003^{2}\end{array}$} \\
\hline & Canada & $\begin{array}{l}\text { New } \\
\text { Zealand }\end{array}$ & $\begin{array}{l}\text { The } \\
\text { Netherlands }\end{array}$ & $\begin{array}{l}\text { United } \\
\text { Kingdom }\end{array}$ & \\
\hline Milk & 0.69 & 0.44 & 0.44 & 0.52 & 0.65 \\
\hline Fat & 0.63 & 0.52 & 0.55 & 0.74 & 0.73 \\
\hline Protein & 0.85 & 0.77 & 0.70 & 0.82 & 0.82 \\
\hline PL & 0.36 & 0.45 & 0.62 & 0.49 & 0.50 \\
\hline SCS & -0.19 & -0.21 & -0.42 & -0.24 & -0.31 \\
\hline DPR & -0.08 & 0.25 & 0.29 & 0.05 & 0.10 \\
\hline SSCE & -0.06 & -0.22 & -0.35 & -0.15 & -0.21 \\
\hline DCE & -0.06 & -0.13 & -0.33 & -0.10 & -0.17 \\
\hline Udder & 0.29 & -0.14 & 0.07 & 0.02 & 0.10 \\
\hline Feet and legs & 0.29 & -0.07 & 0.12 & 0.11 & 0.12 \\
\hline Size & 0.11 & -0.48 & -0.14 & -0.11 & -0.11 \\
\hline
\end{tabular}

${ }^{1}$ Traits: $\mathrm{PL}=$ productive life DPR = daughter pregnancy rate; SSCE = service sire calving ease DCE = daughter calving ease.

${ }^{2}$ The US Lifetime Net Merit index. in the late 1970s. Largely under leadership of the American Jersey Cattle Association, processors, especially cheese manufacturers, began paying protein premiums to producers of all breeds. In response, DHI programs ultimately included protein as a standard part of the testing program. Percentage of cows with genetic evaluations for protein increased rapidly from $34 \%$ for cows born in 1977 to $60 \%$ in 1979 and $91 \%$ in 1983.

Selection indexes are formulated with component yields rather than percentages because their economic values are independent. Conversely, when indexes are formulated in terms of component percentages, the value of additional milk volume depends on component percentages and the values of increased component percentages depend on milk volume. Milk volume is defined as milk with no fat and no protein. Over time, the economic values of fat yield and milk with average fat and protein content have been relatively stable. However, protein values have increased with corresponding decreases in value of milk volume.

Among 13 countries surveyed in 2004, percentage relative economic weights for yield traits ranged from 29 and $34 \%$ in Denmark and Sweden to a high of around $75 \%$ in the United Kingdom and Japan. In part, countries with lower yield weights provide genetic evaluations for a larger number of nonyield traits. Eight countries, including the United States, had weights near zero for milk volume and 4 countries used strongly negative weights of around 15 to $20 \%$. All countries had higher weights for protein than fat. Ratios of weights for protein:fat ranged from a low of 1.5 in the United States to highs of 7 and 5 in New Zealand and The Netherlands. Ratios in most countries were between 2 and 4 .

Indexes in Canada and the European Union have been formulated in a manner that accounts for the milk and milk component quotas in effect in those countries. Constraints on a herd's total output requires that herd size must be reduced as production per cow increases. Alternatively, production quotas may be purchased and that cost prorated against the value of increased production per cow.

\section{Feed Cost}

Feed and nutrient intakes are not recorded for individual cows. Instead, bioeconomic models have been used to estimate marginal feed costs associated with genetic gains in milk and component yields. Early models of feed cost were based only on energy requirements and those assumed a constant ratio of protein to fat. That approach was appropriate when selection indexes were based on milk and fat production. The 
introduction of indexes that also included protein required separate accounting for milk protein synthesis because milk protein:fat ratios vary.

An improved bioeconomic model was developed in a 3 -step process. First, biochemical pathways involved in formation of individual milk proteins, fats, and lactose from amino acids, fatty acids, and glycerol were detailed. This step provided independent requirements for metabolizable energy and absorbed true protein for synthesis of each milk component. Step 2 derived the amounts of feeds needed to provide the energy and protein required for synthesis of each milk component. These equations considered digestible undegraded protein, rumen-available protein, and microbial protein synthesis in the rumen as sources of absorbed protein. The final step derived feed cost for each milk component. A high-energy feed (shelled corn) and a high-protein feed (soybean meal) were used to supply nutrients required by genetic gain. Further, it was assumed that the extra requirements due to genetic gain would be met by increasing concentrate intake while maintaining a properly balanced basal forage and concentrate intake.

Feed cost per kilogram of fat was 1.9 times the cost per kilogram of lactose; cost per kilogram of protein was 3.5 times cost per kilogram of lactose and 1.8 times cost per kilogram of fat. The higher feed cost for fat was due to its higher energy content than lactose. The high cost of protein was due to the high requirement for dietary protein and the high cost of protein feeds. Dietary protein requirements for lactose and fat synthesis were low and were due to gluconeogenesis of proteins as an energy source. This approach was implemented in the AIPL merit indexes in 2003.

\section{Somatic Cell Score}

Somatic cell testing was first implemented in DHI programs in the early 1980s for purposes of managing udder health and milk quality. Rapid growth in adoption of somatic cell testing was spurred by milk quality premiums paid to producers and by development of automated laboratory equipment that allowed lowcost testing. Genetic evaluations for SCS in the United States have been published since 1994.

Among early concerns was how to present SCC data. The 7 dairy records processing centers operating in 1981 used diverse methods of reporting somatic cell test results to producers. It was well known that SCC data did not conform to the desired Normal frequency distribution and there were other statistical anomalies. Studies found that the logarithmic transformation of SCC produced data with Normal distribution, increased heritability, reduced heterogeneity of within-herd and within-sire variances, and had a stronger correlation of SCS with bacterial culture results and milk yield. A base 2 logarithm produced an easily remembered association between SCC and SCS in which each 1-point increase in SCS was associated with a doubling of SCC and the scores ranged between 1 and 10: $\mathrm{SCS}=\log _{2}$ [SCC (cells per $\left.\left.\mathrm{mL}\right) / 100,000\right]+$ 3 . This was recommended by the Research Committee of the National Cooperative Dairy Herd Improvement Program (NCDHIP) and adopted as the national standard by the NCDHIP Policy Board in 1982 .

Early estimates of the genetic correlation between SCC or SCS and clinical mastitis were few and based on small data sets, so there was uncertainty about how effective selection would be on SCS to reduce clinical mastitis. Furthermore, the hypothesis was that the genetic relationship between SCS and clinical mastitis might be nonlinear with the lowest clinical mastitis occurring with intermediate SCS. The evidence now indicates a direct genetic relationship between the traits, so animals with lowest PTA-SCS produce progeny with lowest clinical mastitis. Consensus now is that genetic correlation of SCS with clinical mastitis is $0.70 \pm 0.10$. Furthermore, heritability is higher for SCS (0.10 to 0.15$)$ than clinical mastitis (0.03 to 0.06$)$, which also favors SCS as a trait for indirect selection for mastitis. Thus, SCS is a viable indicator trait on which to base indirect selection against clinical mastitis.

Use of genetic evaluations for SCS in the United States has been slow but increasing. There was early concern that the trait would be overemphasized by producers, so the information was undersold and not well publicized. The trait was likely a net loss for the AI industry because a high PTA-SCS would be grounds for discriminating against a bull whereas a low PTASCS would not be valued to an extent that would offset any revenue loss from high SCS bulls. Veterinarians and other specialists in udder health and milk quality focus on management and are not well grounded in genetic improvement programs. At the same time, personnel in the dairy genetics industry were focused on type and production and gave modest attention to SCS. It was a trait without an advocate. Being unsure about its proper economic value, early indexes underemphasized SCS. These situations have improved slowly, and increasing attention is being given to genetic improvement of udder health and milk quality.

Livestock Improvement Corporation in New Zealand has conducted the most comprehensive and detailed economic analysis of SCS. Using empirical analysis and bioeconomic modeling, they developed specific marginal increases in production costs associated with marginal increases in SCS. Several studies 
have shown that indexes that include SCS or clinical mastitis have slightly faster rates of genetic gain in TEM, and modestly reduced rates of increase in milk production. Moreover, this work has shown that indexes that produce the greatest increase in TEM do not actually reduce clinical mastitis and SCS, but they do reduce the rate of increase by 25 to $75 \%$. This is due to the unfavorable genetic correlation of yield with clinical mastitis and SCS, and to the greater economic value and genetic variation for yield. Substantially reduced rates of improvement in both yield and TEM result from indexes that constrain genetic change in clinical mastitis to zero. Among countries, percentage relative economic weights for udder health ranged from 3\% in Canada and Spain to $13 \%$ in France. The US weight was near the median value of $9 \%$.

\section{Herd Life}

Genetic evaluations for herd life were introduced in 1994. This is one of the most complex traits in terms of measurement, analysis, and derivation of economic weights. Contributing to the complexity is that selection of breeding animals must be done early in their life cycles, long before true herd life is known. Selection, therefore, depends on information from ancestors, forecasts of herd life based on individuals' own conformation and early performance records, and on PTA for correlated traits.

Several measures of herd life have been used. Examples are probability of survival to a given age; for example, 48 or $72 \mathrm{mo}$, and months from first calving to removal from the herd or to a given age. Early time points make it possible to define an animal's herd life within a shorter time frame, but they completely disregard ultimate length of herd life. In the United States, months in milk is accumulated from first calving to 84 mo of age with a maximum of 10 mo per lactation. The 84-mo end point was chosen because it had higher heritability than did earlier times. A frequently debated issue is whether herd life should be measured as total herd life or functional herd life. Functional herd life is total herd life adjusted for milk yield. Historically, high-yield cows were retained in herds for a longer time, so total herd life had a moderately high correlation with milk yield. Although higher-producing cows tend to have longer herd life due to voluntary culling, they also tend to experience more metabolic disease and reproductive failure. Producers invest increasingly in treatment and management costs as production increases, so a diminishing net income per kilogram of milk results at higher production levels. Adjusting herd life for yield removes variation that is due to both voluntary and involuntary reasons. As a result, functional herd life only partially captures variation due to reproduction and health. Consensus has not been reached as each measure is used in different countries. The distinction between functional and total herd life appears to be decreasing because culling based on low production is decreasing whereas culling based on reproductive failure and other health-related reasons is increasing.

Economic value of herd life derives from a reduction of rearing cost viewed in terms either of per cow-month in production or per unit of production. Also, increasing the average age of production results in somewhat higher milk yields per lactation, but this is partially offset by higher health and reproduction costs. A nonlinear, multiplicative relationship between production and herd life also complicates economic analysis: the value of extended herd life is greater for higher-producing cows and, conversely, the value of increased production is greater when herd life is longer. This has been appropriately resolved by evaluating each trait at the mean value of the other. The economic value of an additional month of herd life depends on many interacting factors that include rearing costs, culling rates, market values of replacement animals, fertility rates, survival rates from birth to first calving, and whether the enterprise has a stable or expanding herd size. Accordingly, the value of herd life varies among herds and fluctuates over time. The most appropriate approaches for determining economic value are based on whole enterprise analyses implemented in linear or dynamic programming models. A simpler partial budgeting approach of income minus cost has been applied in the United States. Economic weight for herd life also depends on what other traits are in the index. For example, a higher economic value for herd life must be used in an index that does not include reproduction or health. Among countries, percentage relative economic weights range from 3 to $25 \%$. Most countries, including the United States, use weights between 8 and $12 \%$.

\section{Type}

Two important innovations in type evaluation were developed in the past quarter-century: a linear scoring approach and composite type traits. Linear type scores, implemented in the early 1980 s, characterize the physical dimensions of specific conformation traits. For example, linear score for udder depth indicates the distance of the udder floor above (low score) or below (high score) the point of the cow's hock. Seventeen aspects of body conformation are scored in this manner. Linear scores, unlike previous scoring sys- 
tems, do not attempt to characterize the desirability of an animal's type.

Relationships between the linear type traits and animal performance have been analyzed to determine what are the most desirable linear score ranges. Linear type scoring has enabled the discovery of type characteristics that contribute to improved herd life, udder health, and metabolic health. To simplify selection for type, the several linear traits are combined into composite indexes for udder, feet and legs, body size, and dairy capacity. Individual traits within each composite index are weighted according to their association with functional herd life. Several studies have determined the relationship of the linear udder traits with clinical mastitis or SCS, but these relationships have not been used in the formulation of udder composite.

Type traits have direct economic value in the purebred sector where animals are promoted and traded mostly on type. For some, these traits have esthetic if not real economic value. In the much larger commercial sector, type is most useful as a predictor of nonyield performance. The prestige accorded to outstanding type by prominent dairy shows has skewed the application of selection indexes toward the purebred sector. Although selection indexes play a role in sire procurement decisions, those decisions are not based on indexes alone. Type and popularity (driven in part by advertising) of prospective sires and dams, also, play importantly into selection decisions.

Leadership in the AI industry has disproportionately come out of the purebred sector. Personnel, especially those in sire procurement and marketing, are largely recruited from the ranks of university judging team graduates because they have superb training in evaluating and communicating on matters of type. Advertising, likewise, is designed to appeal more strongly toward the purebred sector, perhaps because that sector is willing to invest more heavily in top-value semen. The breed associations, naturally and appropriately, promote the interests of the purebred sector. There is no counterpart in the commercial sector; as a result, the purebred sector has a substantially stronger voice than the commercial sector in the formulation of selection indexes and other genetic improvement issues. On the other side of the coin, the research community is perhaps skewed toward the interests of commercial producers. In the final analysis, perhaps it is appropriate that the USDA merit indexes are formulated mostly for commercial producers whereas the breed associations formulate indexes for the purebred sector.

An accompanying article in this issue by D. A. Funk reviews a history of Holstein Association selection indexes. The percentage relative weight on type increased from $20 \%$ in 1980 to $30 \%$ in 2004 . The USDA merit indexes included type for the first time in 1994, and then only indirectly as an early predictor of productive life. Type has been directly included since 2000 . Wide variation exists among countries in the availability of type data and its use in selection indexes. Percentage relative economic weights range from 32 and 35\% in Canada and Spain to 3\% in The Netherlands and United Kingdom. The United States is just below the median relative weight of $15 \%$. The 3 categories of traits most often included in indexes, in decreasing order of importance, were udder, feet and legs, and size. In general, udder traits were weighted 3 to 4 times as much as size and feet and legs were weighted 2 to 3 times as much as size. An exception was New Zealand where size was the only type trait indexed, and its relative weight was $-15 \%$.

\section{Reproduction}

The percentage of herds in the United States reporting breeding and pregnancy diagnosis dates has traditionally been low and, in many herds, sporadic. This situation has been improving, and much of the improvement can be attributed to the development of herd management software, larger herd sizes that require the use of software, and development of interfaces between herd management software and DHI. Still, availability of data for genetic evaluation is less than desired.

Optimal reproductive performance with AI depends on a complex of interacting factors. Two measures most commonly used in European genetic evaluations are days from calving to first breeding and nonreturn rate within, for example, $56 \mathrm{~d}$ after first insemination. Days to first breeding is influenced by factors such as uterine health, endocrine function, and estrus expression, and provides a general measure of reproductive health. Increasingly, in US production systems, days to first breeding is also influenced by estrous synchronization protocols that diminish its usefulness for genetic evaluation. Nonreturn rates are strongly correlated with conception rates but are higher than conception rates. In addition to pregnancy, nonreturn may result from culling or unrecorded subsequent breeding among other factors. Routine veterinary pregnancy diagnosis is increasingly being recorded in data systems and offers the possibility of more precise recording of conception rates.

Genetic evaluations for reproduction were available as early as the late 1970s in Norway and Sweden. Several other European countries introduced genetic evaluations in the mid 1990s. In 2003, AIPL introduced evaluations for female reproductive performance called daughter pregnancy rate. This is based 
on a conversion of days open or calving interval with a 4 -d decrease in days open equating to a $1 \%$ increase in pregnancy rate. A principal advantage for this conversion is that higher values of daughter pregnancy rate indicate better performance. Days open are determined variously depending on what information is available in the DHI record. Approximately $8 \%$ of cows are excluded from daughter pregnancy rate evaluations for lack of breeding dates or subsequent calvings.

Economic values for reproductive traits have been estimated from partial budgets, bioeconomic models, and whole herd simulations. Economic importance of reproduction has many factors in common with herd life. Values for the 2 traits should be determined simultaneously to derive the economic value of each at fixed levels of the other. Ideally, economic values should be assessed by simulation of the whole enterprise. Production systems that require calving in a single season (small variation in calving interval is required) demand a higher economic value for reproduction than systems based on year-round calvings (larger variation in calving interval is acceptable). Studies have varied widely in costs associated with differences in reproductive performance. Also, economic value of reproduction varies among herds and over time. For example, economic value increases with decreased herd fertility level, increased cost of replacement animals, and decreased cull cow values. Among 13 countries surveyed in 2004, 7 included reproduction in their selection indexes. At the high end, France, New Zealand, and Sweden placed relative weights of 10 to $13 \%$ on fertility; relative weights in other countries, including the United States, were 7 to $9 \%$.

A national evaluation for male fertility has been conducted by Dairy Records Management Systems (Raleigh, NC) since 1988. This evaluation, called estimated relative conception rate, is based on nonreturn to service at $70 \mathrm{~d}$ after first insemination. This program encompasses about $25 \%$ of cows in the production records program. Due to the requirement for at least 300 first inseminations within $3 \mathrm{yr}$, only bulls with secondcrop daughters are evaluated. Consequently, only about $60 \%$ of active AI bulls have estimated relative conception rate evaluations, and these become available only 1 to 2 yr after a bull enters active AI status. An advantage for evaluations based on nonreturn or veterinary diagnosis of conception rate is that male and female fertility can be evaluated simultaneously. Genetic correlation for nonreturn rate between service sire (male fertility) and sire of cow (female fertility) have not been established with precision as estimates vary widely and have large standard errors. Male fertility, so far, has not been incorporated into the AIPL lifetime merit indexes.

\section{Calving Ease}

Calving ease in the United States is coded in 5 progressive categories ranging from no assistance or unobserved calving to extreme difficulty. Frequency of difficult births averages around 8 and $3 \%$ in first and later parity calvings, respectively. Calving ease is influenced by factors associated with the calf and another set of factors due to the cow. Consequently, 2 kinds of evaluations are published: service sire calving ease (SSCE) and daughter calving ease (DCE). Service sire calving ease measures the effect of the sire of the calf (i.e., service sire of the cow). Birth weight is an example of a calf trait that affects calving ease and is influenced by the sire of the calf. Daughter calving ease reflects the effect of the cow (and her sire) on the calf; for example, through birth weight. In addition, DCE measures the ability of the cow to have an easy delivery. The latter is affected by, e.g., pelvic anatomy and maternal physiological factors. The cow's sire affects both the calf and cow factors.

Evaluations of SSCE have been published in the United States since 1978, and DCE evaluations have been available in some countries for many years and were implemented in the US in 2002. Genetic evaluations for calving ease are available for approximately $55 \%$ of cows with yield PTA. Both SSCE and DCE evaluations in the United States are expressed as a percentage of difficult births in first-parity calvings. Difficult births are those in the 2 highest categories of the reporting system. High values of SSCE and DCE indicate more difficult calving, rather than easier calving that the name implies. Calving ease evaluations are used in 2 ways: They are weighted in selection indexes and thus included in selection decisions among bulls; and they are used in mating schemes to preferentially mate yearling heifers with bulls having favorable SSCE ratings.

Costs of calving difficulty derive from increases in calf mortality, veterinary fees, herd labor, and cow culling as well as decreases in milk production and reproductive performance. Calf mortality increases from around 5\% for the "no problem" births to more than $25 \%$ for the 3 most difficult birth categories. Days open are 16 and $32 \mathrm{~d}$ greater in the 2 most difficult birth categories, respectively, compared with the "no problem" category regardless of parity. A 2004 survey of selection indexes in 13 countries found that 5 indexes included calving traits. Percentage relative economic weights ranged from $4 \%$ in the United States to $12 \%$ in Sweden.

\section{MARKER-ASSISTED SELECTION}

Considerable research effort has been expended in developing genetic marker maps, associations of mark- 
ers with performance traits, and strategies for using markers in breed improvement. As of 2004, 3,802 microsatellite markers had been developed for cattle. The goal is to use markers as an adjunct to conventional selection that is based on PTA for performance traits. Much of the work to date has been limited to traits in national dairy genetic evaluation programs and for Holstein type traits. These studies have identified many chromosome regions with potentially useful major genes.

Direct markers are locations on chromosomes that code for specific functions; in other words, they are actually functioning genes. This is the most desirable kind of marker because it has a direct biological connection with phenotypic expression. Direct markers are the most difficult to detect because causality is difficult to prove, especially for traits with quantitative phenotypes and polygenic inheritance. The best known examples are the acylCoA:diacylglycerol acyltransferase (DGAT1) gene and growth hormone receptor gene, both of which have large effects on milk yield and composition. Direct markers are more easily detected for congenital defects than for quantitative traits. Well-known examples are the genes for bovine leukocyte adhesion deficiency, citrullinemia, deficiency of uridine monophosphate synthase, and complex vertebral malformation. Other examples are genetic variants of the milk proteins $\kappa$-casein and $\beta$-lactoglobulin.

Easier to detect but slightly limited in usefulness are linkage disequilibrium markers. These are typically within a few centimorgans of the functional gene and, like direct markers, can be applied across families. An early example published in 1990 was a marker near the prolactin gene with effects on milk yield and composition. Linkage equilibrium markers, a third marker type, are the easiest to discover but are limited in their usefulness for selection. Large half-sib families facilitate identification of these markers; so much of the work in dairy cattle has been with this marker type. Linkage equilibrium markers are useful only for selection within families. They are typically located further from the functional gene, so recombination can more often reverse the linkage phase between marker and functional gene alleles from generation to generation diminishing their usefulness for selection, even within families.

The use of direct markers (causative genes) in the AI industry to prevent congenital defects is well known and highly effective. Prospective young bulls are screened for recessive alleles, and heterozygous bulls are not entered into progeny testing. Progeny of bulls homozygous for the normal allele are not affected by the recessive lethal condition, and frequency of the defective allele in the cow population is reduced by one-half each generation.

Many studies have been conducted to evaluate strategies for use of molecular genetic information in selection programs. Factors that favor identification of major genes are high heritability, progeny-tested bulls with large numbers of daughters, and loci with large effects. These also favor conventional selection that is based on phenotypes of close relatives. Ironically, usefulness of markers is greater for traits with low heritability and for which progeny-testing possibilities are limited by the lack of performance data-the very conditions that make them difficult to detect. Commercial application of markers to improve polygenic traits is limited and much of this research is proprietary and undocumented. Some organizations appear to be successfully using markers to select dams of bulls and to preselect among young bulls before submitting them to progeny test. The greatest need and greatest potential for marker-assisted selection is for health, survival, and fertility. Much more effort will be required to discover marker associations for traits that are not routinely recorded in field data.

The DGAT1 gene provides an example of both the opportunity and the dilemma faced in application of marker-assisted selection. The lysine allele of DGAT1 produces a strongly favorable effect on milk fat percentage and fat yield. In contrast, the alanine allele favors high milk and protein yields. Effects of DGAT1 on health and reproduction traits are not known. Assuming the nonyield effects are negligible, the current Lifetime Net Merit index in the United States indicates a positive economic value for the alanine allele and negative value for the lysine allele. Dairy markets and selection indexes in some other countries, however, favor the lysine allele. Studies in New Zealand have found that cows with a high percentage of genes of North American ancestry have a high (70\%) frequency of the alanine allele whereas cows with mostly New Zealand ancestry have a high frequency of the lysine allele. These contrasting allele frequencies are a result of several generations of conventional selection for fat percentage in New Zealand and for milk yield in North America. Because frequency of the desired allele is already high in each country, markerassisted selection for the DGAT1 locus has limited utility.

\section{CONCLUSIONS}

\section{Looking Back}

Exceptional progress has been made in selection index applications. Change has occurred with increasing frequency. However, a critical review reveals possible 
future changes. Many advances have depended on new opportunities, especially genetic evaluations for new traits. Here, the focus is on opportunities that existed but were not taken.

In formulating future indexes, it may be advised to consider the effect of supply and demand curves on milk prices. Theoretical studies have already considered this approach. Milk supply is more immediately a function of cow numbers than production per cow. Nevertheless, production per cow is a factor in market supply. Increasing supply in the absence of an increase in demand puts downward pressure on milk prices. These forces have not been considered in US selection indexes. Accordingly, selection emphasis on nonyield traits should be increased relative to yield traits.

The most important advance in selection indexes has been the introduction of nonyield traits. In retrospect, this more balanced approach to selection should have been implemented earlier. The basic data on which daughter pregnancy rate and productive life evaluations are based were available for many years before these evaluations were developed. Justification had been that the gains in revenue from increased yield more than offset the increased costs due to losses in health and fertility associated with selection for yield. Profitability would have increased more rapidly had the nonyield traits been included in indexes earlier than they were. Studies have shown that modest selection emphasis on the nonyield traits can substantially reduce their decline while sacrificing a relatively small amount of genetic gain in production.

In most studies, economic weights for nonyield traits have been limited to documentable revenues and costs. As a result, nonyield traits have been undervalued. Intangible benefits of reduced disease and fertility, such as improved animal well being, decreased diagnostic and management costs, and reduced use of antibiotics, should be included in future index formulations.

\section{Looking Ahead}

Current research provides a window into selection indexes of the future. As genetic parameters and economic values are developed, the new traits will be incorporated into increasingly comprehensive selection indexes. Research shows promise for body condition score as an indicator trait for metabolic disease. Studies in Europe and more recently in the United States are developing genetic evaluations for milk fever, ketosis, and displaced abomasum. Research in progress will lead to genetic evaluations for stillbirth and calf survival. Male fertility evaluations have been conducted at North Carolina State University for more than a decade. All of these traits represent important cost factors that should be included in selection indexes. Advances for these and other traits will be constrained by the lack of performance data submitted to central databases by commercial producers. Improvements in data systems are needed to increase reporting for these traits.

Recent research indicates the need for a larger role for body size and dairyness in selection indexes. Dairy judges have given these traits strong emphasis in show rings. Accordingly, the AI industry and dairy producers have bred increasingly larger and thinner cows. A long term selection trial for large vs. small body size has been conducted in Minnesota. Culling rates and health costs have been substantially greater in the large body size line. Studies in the United States and the United Kingdom have found moderately to strongly unfavorable genetic and phenotypic correlations of body condition score and dairy form with reproductive performance and metabolic disease. Cows with intermediate body condition and dairy form are less susceptible to disease and have fewer days open. Selection indexes and mating recommendations should be modified to produce cows with optimal size and body condition.

Selection of breeding animals has become burdened with information overload. Currently, genetic evaluations are produced for 10 performance traits and 20 conformation traits; more will be available in the future. One cannot easily identify the most desirable animals from such an array of raw information. A wellformulated selection index is the best approach to summarizing PTA in a way that leads to optimum economic improvement. Studies have shown that economic values of survival, fertility, and health vary with the quality of herd management. Moreover, producers have individual goals and needs that differ from those of the general population. Individualized selection indexes for each herd would enable producers to attain unique goals for their specific environment. Subindexes are an intermediate approach that has been taken in some countries. For example, subindexes could be formulated for production, reproduction, udder health and milk quality, herd life, calving performance including calf survival, and type. Individual traits are used in the subindexes and these, in turn, are combined into an overall index. Producers, then, could focus on the subindexes in formulating their own overall indexes.

Crossbreeding is almost certain to become an important strategy in dairy cattle breeding in the years ahead. Remarkably, dairy is the only agricultural industry that has not exploited the phenomenon of hybrid vigor. Selection indexes will need to undergo a 
major shift as crossbreeding becomes more widely used. Until now, the unit of performance in indexes has been the cow-lactation and, more recently, the cow-lifetime. These cow-based measures perform well for comparing animals within breeds in which animals have relatively uniform characteristics. Because of large differences among breeds in cow size, milk production, and milk composition, the unit of performance will need to become breed neutral; that is, equitable with respect to breed differences in performance and body size. Several studies conclude that economic efficiency, or revenue divided by cost of production, is the most appropriate measure.

Success of research in molecular genetics in dairy cattle will be accelerated by 3 technologies. First, the recently completed bovine genome sequence will facilitate more rapid discovery of candidate genes and subsequently of functional genes. Second, comparative genome maps and genome sequences across species, especially of cattle with human and mouse, will enable transfer of discoveries from other species to cattle. Third, increased use of crossbreeding in both commercial and experimental settings will enable discovery of chromosome regions that harbor genes with large effect. The tools for locating major genes will continue to improve in terms of reduced cost and greater power of detection. Discovery of the major genes that cause breed differences will enable formation of composite breeds with the most favorable alleles from each of the donor breeds and allow marker-assisted introgression of desirable alleles from one breed to another. As major genes are identified, their effects will be incorporated into genetic evaluations and selection indexes.

\section{ACKNOWLEDGMENT}

The author extends sincere appreciation to L. B. Hansen for many helpful suggestions during development of this manuscript.

\section{REFERENCES}

Balaine, D. S., R. E. Pearson, and R. H. Miller. 1981. Profit functions in dairy cattle and effect of measures of efficiency and prices. J. Dairy Sci. 64:87-95.

Brascamp, E. W. 1984. Selection indices with constraints. Anim. Breed. Abstr. 52:645-654.

Clay, J. S., and B. T. McDaniel. 2001. Computing mating bull fertility from DHI nonreturn data. J. Dairy Sci. 84:1238-1245.

Dado, R. G., G. E. Shook, and D. R. Mertens. 1994. Nutrient requirements and feed costs associated with genetic improvement in production of milk components. J. Dairy Sci. 77:598-608.

Dekkers, J. C. M. 1993. Theoretical basis for genetic parameters of herd life and effects on response to selection. J. Dairy Sci. 76:1433-1443.

Dekkers, J. C. M. 1994. Optimal breeding strategies for calving ease. J. Dairy Sci. 77:3441-3453.
Dekkers, J. C. M. 2004. Commercial application of marker- and gene-assisted selection in livestock: Strategies and lessons. J. Anim. Sci. 82(E Suppl.):E313-E328.

Dekkers, J. C. M., P. V. Birke, and J. P. Gibson. 1995. Optimum linear selection indexes for multiple generation objectives with non-linear profit functions. Anim. Sci. 61:165-175.

Dekkers, J. C. M., and J. P. Gibson. 1998. Applying breeding objectives to dairy cattle improvement. J. Dairy Sci. 81(Suppl. 2):19-35.

Dematawewa, C. M. B., and P. J. Berger. 1997. Effect of dystocia on yield, fertility, and cow losses and an economic evaluation of dystocia scores for Holsteins. J. Dairy Sci. 80:754-761.

Gibson, J. P. 1987. The options and prospect for genetically altering milk composition in dairy cattle. Anim. Breed. Abstr. 55:231243.

Gibson, J. P. 1989. Selection on the major components of milk: Alternative methods of deriving economic weights. J. Dairy Sci. 72:3176-3189.

Goddard, M. E. 1983. Selection indices for non-linear profit functions. Theor. Appl. Genet. 64:339-344.

Goddard, M. E. 1998. Consensus and debate in the definition of breeding objectives. J. Dairy Sci. 81(Suppl. 2):6-18.

Grisart, B., W. Coppieters, F. Farnir, L. Karim, C. Ford, N. Cambisano, M. Mni, S. Reid, R. Spelman, M. Georges, and R. Snell. 2002. Positional candidate cloning of a QTL in dairy cattle: Identification of a missense mutation in the bovine DGAT1 gene with major effect on milk yield and composition. Genome Res. $12: 222-231$

Groen, A. F., J. A. M. van Arendonk, M. E. Goddard, and A. R. Vollema. 1997. On the use of opportunity costs in deriving the economic value of herd life. Anim. Sci. 65:335-341.

Hansen, L. B., J. B. Cole, G. D. Marx, and A. J. Seykora. 1999. Productive life and reasons for disposal of Holstein cows selected for large versus small body size. J. Dairy Sci. 82:795-801.

Harris, B. L., J. M. Clark, and R. G. Jackson. 1996. Derivation of the economic weights for the breeding worth, production worth and lactation worth indices. Tech. Rep. Livest. Improvement Corp., Hamilton, New Zealand.

Hazel, L. N. 1943. The genetic basis for constructing selection indexes. Genetics 28:476.

Hazel, L. N., G. E. Dickerson, and A. E. Freeman. 1994. The selection index-Then, now, and for the future. J. Dairy Sci. 77:32363251.

Ihara, N., A. Takasuga, K. Mizoshita, H. Takeda, M. Sugimoto, Y. Mizoguchi, T. Hirano, T. Itoh, T. Watanabe, K. M. Reed, W. M. Snelling, S. M. Kappes, C. W. Beattie, G. L. Bennett, and Y. Sugimoto. 2004. A comprehensive genetic map of the cattle genome based on 3802 microsatellites. Genome Res. 14:1987-1998.

Kelm, S. C., A. E. Freeman, and NC-2 Technical Committee. 2000. Direct and correlated responses to selection for milk yield: Results and conclusions of regional project NC-2, Improvement of dairy cattle through breeding with emphasis on selection. J. Dairy Sci. 83:2721-2732.

Khatkar, M. S., P. C. Thomson, I. Tammen, and H. W. Raadsma. 2004. Quantitative trait loci mapping in dairy cattle: Review and meta-analysis. Genet. Sel. Evol. 36:163-190.

Kulak, K. K., J. C. M. Dekkers, A. J. McAllister, and A. J. Lee. 1997. Lifetime profitability measures for dairy cows and their relationships to lifetime performance traits. Can. J. Anim. Sci. 77:609-616.

Miller, R. H., and R. E. Pearson. 1979. Economic aspects of selection. Anim. Breed. Abstr. 47:281-290.

Mrode, R. A., and G. J. T. Swanson. 1996. Genetic and statistical properties of somatic cell count and its suitability as an indirect means of reducing the incidence of clinical mastitis in dairy cattle. Anim. Breed. Abstr. 64:847-856.

Pearson, R. E., and R. H. Miller. 1981. Economic definition of total performance, breeding goals, and breeding values for dairy cattle. J. Dairy Sci. 64:857-869.

Pecsoc, S. R., M. L. McGilliard, and R. L. Nebel. 1994. Conception rates. 1. Derivation and estimates for effects of estrus detection on cow profitability. J. Dairy Sci. 77:3008-3015. 
Philipsson, J., G. Banos, and T. Arnason. 1994. Present and future uses of selection index methodology in dairy cattle. J. Dairy Sci. 77:3252-3261.

Plaizier, J. C. B., G. J. King, J. C. M. Dekkers, and K. Lissemore. 1997. Estimation of economic values of indices for reproductive performance in dairy herds using computer simulation. J. Dairy Sci. 80:2775-2783.

Rogers, G. W. 1993. Index selection using milk yield, somatic cell score, udder depth, teat placement, and foot angle. J. Dairy Sci. 76:664-670.

Schutz, M. M. 1994. Genetic evaluation of somatic cell scores for United States dairy cattle. J. Dairy Sci. 77:2113-2129.

Shook, G. E., and M. M. Schutz. 1994. Selection on somatic cell score to improve resistance to mastitis in the United States. J. Dairy Sci. 77:648-658.

Short, T. H., and T. J. Lawlor. 1992. Genetic parameters of conformation traits, milk yield, and herd life in Holsteins. J. Dairy Sci. 75:1987-1998.

Smith, C., J. W. James, and E. W. Brascamp. 1986. On the derivation of economic weights in livestock improvement. Anim. Prod. 43:545-551.

Spelman, R. J., C. A. Ford, P. McElhinney, G. C. Gregory, and R. G. Snell. 2002. Characterization of the DGAT1 gene in the New Zealand dairy population. J. Dairy Sci. 85:3514-3517.

Van Vleck, L. D. 1993. Selection Index and Introduction to Mixed Model Methods. CRC Press, Boca Raton, FL.
VanRaden, P. M. 2004. Invited Review: Selection on net merit to improve lifetime profit. J. Dairy Sci. 87:3125-3131.

VanRaden, P. M., and A. J. Seykora. 2003. Net merit as a measure of lifetime profit: 2003 revision. Available at: http://aipl.arsusda.gov/reference/nmcalc.htm Accessed Feb. 6, 2004.

VanRaden, P. M., and G. R. Wiggans. 1995. Productive life evaluations: Calculation, accuracy, and economic value. J. Dairy Sci. 78:631-638.

VanRaden, P. M., and G. R. Wiggans. 2003. Methods used to compute multi-trait productive life. http://aipl.arsusda.gov/reference/ multi-pl.htm Accessed Feb. 10, 2005.

Weigel, D. J., B. G. Cassell, and R. E. Pearson. 1995. Adjustment of a net income function for opportunity cost of postponed replacement on a lactation basis. J. Dairy Sci. 78:648-654.

Weigel, K. A., T. J. Lawlor, Jr., P. M. VanRaden, and G. R. Wiggans. 1998. Use of linear type and production data to supplement early predicted transmitting abilities for productive life. J. Dairy Sci. 81:2040-2044.

Weller, J. I. 1994. Economic Aspects of Animal Breeding. Chapman and Hall, New York, NY.

White, J. M., W. E. Vinson, and R. E. Pearson. 1981. Dairy cattle improvement and genetics. J. Dairy Sci. 64:1305-1317.

Winkelman, A. M. 2003. Calculation of the economic weight for somatic cell count for inclusion in the New Zealand dairy cattle breeding objective. Tech. Rep. Livest. Improvement Corp., Hamilton, New Zealand. 